\title{
Returning Government Policy for Poverty Reduction in Aceh
}

\author{
Ernita Dewi ${ }^{1}$, Munawiah ${ }^{1}$, Siti Nurzalikha ${ }^{1}$ \\ State Islamic University of Ar-Raniry Banda Aceh, Indonesia \\ ernitadewi143@gmail.com
}

\begin{abstract}
Aceh and Bengkulu are included in the top list of the poorest regions of Sumatra, in fact, are in the top ten in Indonesia. Aceh with a large budget both from APBA, special autonomy funds and oil and gas revenue sharing funds, but poverty is still a fetter for the people of Aceh. It is not wrong if many question the government policies that are always echoed to alleviate poverty. This paper wants to describe in detail the government policies in alleviating poverty, it is right on target or it still dwells on the poverty alleviation discourse, and programs that are proclaimed are only limited to ideals that are not in accordance with the reality and needs of society.
\end{abstract}

Keywords: poverty; government policy; Aceh; Bengkulu

\section{Introduction}

According to BPS Aceh ${ }^{1}$ data, in March 2018, the number of poor people in Aceh reached 839 thousand people (15.97 percent), an increase of 10,000 people compared to the poor population in September 2017, which amounted to 829 thousand people (15.92 percent). Whereas if compared to March of the previous year there was a decline in the number of poor people by 33 thousand people (16.89 percent).

One way to see the failure or success of asymmetrical decentralization that has been attached to Aceh since 2006 is with the conditions of welfare. Welfare is placed as the final destination, while special autonomy is an effort to achieve it. Regarding this matter, the attention was immediately directed towards the Special Autonomy that had been rolled out for Aceh, considering that the amount ranged from 4-5 trillion rupiah per year, certainly not a little. However, if we look at Aceh in general, the strong impression is that the Special Autonomy Fund has not been able to show a significant role in raising people's welfare there. Poverty is still a major problem for Aceh. ${ }^{2}$

In fact, that much money has not been able to be used maximally in raising the standard of living of its people. The unemployment rate in Aceh is still the highest in Indonesia at 9.93 percent. This special autonomy for Aceh has been given since 2008 and will end in 2027. During the 20-year period of the implementation of the Special Autonomy Fund, Aceh is estimated to receive Rp163 trillion. as a form of compensation to regions that have been hit by the armed conflict. The huge amount of funds can actually provide welfare for approximately 5 million Acehnese.

The most basic question is that when so much money is managed by the Aceh government, poverty increases. It is undeniable that the Aceh government has worked hard to provide the best for the people of Aceh, the statement was often uttered by the governor when conveying the progress of development in his leadership period. wrong with the government policy. If government policy is right on target, then the main possibility is that the main

\footnotetext{
${ }^{1}$ Badan Pusat Statistik (BPS) Provinssi Aceh, Profil Kemiskinan dan Ketimpangan Pengeluaran Penduduk Aceh Maret 2018, No. 31/07/Th.XXI, July $16^{\text {th }} 2018$.

${ }^{2}$ Heru Cahyono, "Evaluasi Atas Pelaksanaan Otonomi Khusus Aceh: Gagal Menyejahterakan Rakyat Dan Sarat Konflik Internal”, in Jurnal Penelitian Politik, Vol. IX, No. 2, (2012), page. 3-4.
} 
problem lies in the community itself. Another possibility is the channeling of development funds which are hampered by an agency that does not reach the people. Various assumptions can be raised related to the problematic still high rate of poverty in Aceh.

\section{Review of Literature}

\subsection{Poverty According to Islam}

Islamic religion which is very strict against poverty, Asghar Ali Engineer in his book, Islam and Liberation Theology states that Islam comes with one of the aims of declaring war on poverty, war against unjust rulers who eat public money. Enrich yourself and let people live hard. Islam requires leaders to be fair and uphold justice in all aspects, including economic justice. ${ }^{3}$

Even the Prophet Muhammad in his hadith stated that the hand above was better than the hand below. Fervor is closer to kufr. This tradition becomes important motivation for Muslims to declare war on poverty. Even theologically there is no room to maintain poverty in Islam. The obligation to issue zakat is a vital means for alleviating poverty. Islam also encourages its people to diligently give alms, invest, with one purpose to make weak people strong.

Hassan Hanafi stated that Muslims have never been one people because they are always divided into two poles, namely rich Muslims and poor Muslims. Even in areas that are more extreme, until now there are still found religious people who seem to get a license from God to kill their fellow human beings (license to kill). ${ }^{4}$ Thus we can still divide into oppressive Muslims and oppressed Muslims. This is what needs to be a current religious suit. Therefore, the presence of a religious paradigm that is human and focused on the praxis of awareness, liberation, and resistance is very much needed at this time. Awareness of the poor will be the reality of oppression and poverty that afflicts them, while at the same time providing theological-human inspiration for liberation. Likewise, resistance to human arrogance has been an oppressor.

\subsection{Factors Causing Poverty}

\subsubsection{Structural}

Structural poverty can be interpreted as the standard of living of the population. Only structural poverty is poverty that arises not because of the inability of the poor to work (lazy), but because of the inability of social systems and structures to provide opportunities that enable the poor to work. The social structure is not able to connect the community with the available resources, both those provided by nature, the government and the people around them. Those belonging to this group are farm laborers, scavengers, sand diggers and those who are not educated and untrained. The party that plays a major role in creating this structural poverty is the government, because the government that has power and policy tends to leave the people in poor condition,

does not issue pro-poor policies, even if there are more project oriented, not welfare development. So that there are no poor people who 'go up to class', meaning that in the

\footnotetext{
${ }^{3}$ Asghar Ali Engineer, Islam dan Teologi Pembebasan, Terj. Agung Prihantoro, Cet. II, (Yogyakarta: Pustaka Pelajar, 2000), page. 98.

${ }^{4}$ M. Subhan Setowara, Berteologi Melawan Kemiskinan, dalam KOMPAS, November $6^{\text {th }} 2004$.
} 
beginning workers, fishermen and scavengers will forever become fishermen and scavengers, because there is no effort in raising their degrees and abilities both in education and training opportunities.

\subsubsection{Policy}

The limited access to health services, education, housing and settlements, infrastructure, capital/credit and information for the poor is one of the factors that causes poverty alleviation efforts to be less than optimal.

According to Daryono ${ }^{5}$, the policies made by the government must have a clear strategy, ideally covering the following four things: (1) Policies to promote opportunities, (2) community empowerment policies, (3) capacity building policies , (4) Social protection policies. Besides having a clear strategy, a policy must contain the following principles: siding with the poor, based on the demand of the poor (demand driver), a policy made not to be kept secret, accountability, sustainable responsive, competent, participatory, integrated, targeted, decentralized, democratic, collaborating through networks, and law enforcement.

\subsubsection{Work Ethic}

Apart from structural deterioration, policies that have not been maximized (both in concept and implementation), another thing that is also a factor in poverty still haunts the nation is the low work ethic of the community. This work ethic belongs to what is often called cultural poverty. Unlike structural poverty, cultural poverty actually comes from within individuals and groups in society. Laziness, helplessness, lack of work ethic, and maintained habits cause them to be poor. Therefore, it is their own habits that cause them to not get out of poverty.

Cultural poverty (culture) is caused by lazy attitudes or habits of people who are satisfied with what they have now so that they are trapped in poverty, and also diseases and physical disabilities. This has become very ironic in rural communities because people do not want to try to improve their lives so that the community remains stagnant and does not experience changes in the economic field. ${ }^{6}$ It is clear that cultural poverty originates from within, its own culture that causes it to become entangled in poverty. In humans there are qualities that make someone rich and some make them poor. There is an inherent nature that makes that person so rich as well as the traits that make people support for poverty. In a broader scope, there are traits or characteristics of the nation that make the nation always entangled in poverty, so there is a national character that makes the nation quickly rise from poverty. $^{7}$

\subsubsection{Theology}

According to the modernist understanding - rational understanding and the opposite of traditionalist understanding - the problems faced by the oppressed and the poor, basically the problem is rooted in the problem "because there is something wrong with their mental, cultural, or theological attitude." 8 fundamental causes and problems so that a person or group of people is poor, because it is not right in the theological view.

\footnotetext{
${ }^{5}$ Daryono, "Evaluasi Kebijakan Pengentasan Kemiskinan di Kecamatan Samarinda Utara Kota Samarinda (Menilik Program Nasional Pemberdayaan Masyarakat Mandiri)", dalam Jurnal Administrative Reform, Vol. III, No. 2, (2015), page. 236-237.

${ }^{6}$ Elly M. Setiadi dan Usman Kolip, Pengantar Sosiologi: Pemahaman Fakta dan Gejala Permasalahaan Sosial: Teori, Applikasi Dan Pemecahannya, (Jakarta: Kencana, 2011), p. 798.

${ }^{7}$ Muhammad Istan, "Pengentasan Kemiskinan Melalui Pemberdayaan Ekonomi Ummat Menurut Perspektif Islam", in Jurnal al-Falah, Vol. II, No. 1, (2017), page. 84.

${ }^{8}$ Tasmin, Teologi Kaum Tertindas, (Kediri: STAIN Kediri Press, 2009), page. 115.
} 
That is, poverty is not only considered a mere economic problem, but more important than that is immaterial (theological) poverty. If so, then in a joint effort to alleviate the poverty of our society, first fix community beliefs or theologies which are then followed by reformation in the material field.

However, the opinions above are far different from traditionalist understandings which say that poverty and oppression are God's provisions and plans. ${ }^{9}$ The fact that develops in our society is that there is a belief in the situation that is diala $\neg \mathrm{mi}$ it is a destiny given by Allah SWT. to him, because it can't be avoided anymore. Akirnya gave birth to a view that is completely surrender followed by "emotion" tawakal fully to Allah Swt. The impact is shrinking the effort. Such attitudes and views are often categorized as fatalism. In the relationship of poverty with such attitudes and pandanus, the concept of "culture of poverty" and "structural poverty" was born as mentioned in the previous points.

If religion is to create social piety and avoid being merely solace and a place of complaining, religion must transform itself into a sophisticated tool for making social change, becoming an agent that actively changes the obsolete social order which by itself already has a social-legal and political economy mechanism that is used to defend "high caste" and upper class rights and powers. ${ }^{10}$

Because actually, even though theology comes from scriptural texts revealed by God, some are situational-contextual and normative-metaphysical. His militant spirit appears when theology continues to identify itself with the oppressed. However, the metaphysicalspeculative character will look more prominent when theology identifies itself with establishment which then unites with religious movements. ${ }^{11}$

\section{Discussion}

\subsection{Poverty in Aceh Province}

In March 2018, the number of poor people in Aceh reached 839 thousand people (15.97 percent), an increase of 10,000 people compared to the poor population in September 2017, which amounted to 829 thousand people (15.92 percent). Whereas if compared to March of the previous year there was a decline in the number of poor people by 33 thousand people (16.89 percent).

During the period September 2017 - March 2018, the percentage of poor people in urban and rural areas has increased, in urban areas it has increased by 0.02 percent (from 10.42 percent to 10.44 percent), and in rural areas has increased by 0.13 percent (from 18.36 percent to 18.49 percent).

Food commodities that have a large influence on the value of the poverty line in urban areas are relatively the same as in rural areas, including rice, cigarettes, and tuna / tuna / skipjack. Whereas for non-food commodities that affect the value of the Poverty Line are the costs of housing, gasoline and electricity.

In the period September 2017 - March 2018, the Poverty Depth Index (P1) has decreased from 2,917 in September 2017 to 2,845 in March 2018. Meanwhile the Poverty Severity Index (P2) has decreased from 0.781 in March 2017 to 0.752 in March 2018.

\footnotetext{
${ }^{9}$ Ibid., page. 114 .

${ }^{10}$ Asghar Ali Engineer, Islam dan Teologi Pembebasan, (Pustaka Pelajar: Yogyakarta, 2000), page. 89.

${ }^{11}$ Ibid., page. 90 .
} 
In March 2018, the level of inequality in expenditure of the Acehnese population measured by the Gini Ratio was recorded at 0.325 . This figure has decreased compared to September 2017 which was recorded at 0.329.

The distribution of group expenditure for the lowest 40 percent is 20.49 percent in March 2018. If broken down by region, in the urban area the figure is 19.01 percent, while for rural areas the figure is 22.43 percent.

\subsection{Aceh Government Priority Programs for Poverty Alleviation}

As mentioned earlier, Aceh Province is one of the top 10 regions as the poorest region in Indonesia, although Aceh has a lot of budget both from APBA, special autonomy funds and oil and gas revenue-sharing funds, but poverty still shackles Aceh. For this reason, as stated in the draft Aceh Medium Term Development Plan (RPJM) for 2017-2022, there are 4 (four) poverty reduction strategies in Aceh. The four strategies are:

1. Increased social protection programs;

2. Increasing household access to basic services;

3. Community empowerment

4. Encouraging quality and inclusive economic growth.

According to the Governor of Aceh, Ir. Nova Iriansyah MT at the Regional I Regional Coordination Meeting related to the similarity of perceptions and acceleration of poverty reduction in Aceh, at the Bireuen Regional Secretariat Hall last June, as reported in the website of Kanal Aceh, ${ }^{12}$ that by seeing high poverty levels in Aceh, extra work must be done hard to maximize the four programs mentioned above.

In social protection, the Aceh Government actively provides family-based social assistance such as scholarships for orphans, JKA (Aceh Health Insurance), building and rehabilitating poor people's homes. While in terms of fostering households in basic services, the Aceh Government has facilitated access to basic education services and health services. For quality and inclusive economic growth, the Aceh Government continues to encourage the growth of MSMEs, open connectivity between production centers and markets, accelerate the growth of the real sector, and encourage productive agricultural development.

Pockets of poverty in Aceh are generally in rural areas. Referring to the data released in July 2018 then for the calculation of March 2018 by the Aceh Province Central Statistics Agency (BPS), 20.49 percent of the poverty rate from 22.43 percent was in rural areas. While the poverty rate in urban areas is around 19.01 percent. Referring to this data, if you want to reduce poverty in Aceh, according to the Governor of Aceh, the main focus should be on rural areas or villages.

Aceh Province has a lot of natural resources, coupled with special autonomy funds that reach 14 trillion every year, but the poverty rate in Aceh continues to grow. Addressing this issue, the Head of the Aceh BPS said that the indicator of poverty in Aceh was seen from the inability of the community to consume 52 types of food. The poor are only able to buy rice, but are unable to meet other needs, including the cost of education for their children.

The lack of income is the main factor for the community not being able to fulfill their needs properly. Plus the heads of families who are active smokers, more often prioritizing the

12 Randi, Staretegi Pemerintah entaskan kemiskinan di Aceh, Rubrik "Berita" dalam Kanal Aceh: Berita Terpercaya. See dalam https://www.kanalaceh.com/2018/06/04/staretegi-pemerintah-entaskan-kemiskinan-diaceh/ accessed on September $27^{\text {th }} 2018$. 
needs of cigarettes than household needs. Cigarettes are the main requirement that is not negotiable, even giving up consuming fish, vegetables and fruit. Though income is very minimal, but the need for cigarettes is prioritized. This becomes a bad habit for the community and a factor in poverty. Other poverty indicators in Aceh are related to the high unemployment rate that cannot be overcome until now. Coupled with corruption cases that have made several regional heads arrested by the KPK.

It was admitted that there were indeed many economic empowerment programs such as assistance for seeds, fertilizers, pesticides, but these assistance had not been fully targeted and entered into the heart of the needs of the community categorized as still poor.

For the world of work, Aceh has many vocational graduates, unfortunately these graduates do not have enough skills to be placed in the workforce. Indeed, the government through the BLK can provide training to improve skills for SMK graduates. In order to support their efforts to be able to be independent, the government should provide venture capital, whose guarantee is the government, so that vocational graduates can build their own businesses, this is an attractive offer from the Head of BPS, as an effort to reduce unemployment in Aceh.

The low level of community work ethic also needs to be highlighted, coupled with the minimal support from the government to support the creative economy. For example, many items sold for community needs must be sent from outside the Aceh region. Though there are goods that can be produced in Aceh, but still hope from the outside. Even if it is produced in Aceh, it will accommodate local workers, in addition to improving the economy of the community, as well as creating employment opportunities.

However, economic turnover in Aceh is very dependent on APBA's ratification, if the polemic between the DPRA and the local government occurs, and impacts on the delay in APBA's endorsement, this affects the people of Aceh. The funds should be used for development, when construction is moving, labor will be needed, and goods will be purchased for various needs. This purchasing power will boost the economy of the community on various sides.

The Acehnese people were greatly helped by assistance from the central government, such as Raskin and educational assistance from the Ministry of Social Affairs. However, it is not uncommon, Raskin is shared with those who are not entitled, because of the proximity of the gampong leaders, and feel that they are also entitled to subsidies. Even though accurate data has been provided by BPS, this also triggers conditions of poverty in the community that are difficult to resolve.

BPS hopes that the data given to the regional government to be a reference in taking policies in poverty alleviation. Because all this time, data from BPS has often not been a reference for development planning in an effort to alleviate development.

The Aceh regional planning agency has indeed developed programs for poverty alleviation, but the program has not been maximally benefited by the community. As mentioned by several residents in East Aceh, North Aceh, Bireun and Pidie. That direct touch for economic improvement with the presence of special autonomy has not been felt by remote communities.

The poor infrastructure facilities such as village roads are still an unfinished nightmare. Coupled with the large number of unemployed people in the region. Jobs available only in agriculture, but income is very minimal. The rest are many young people who choose to migrate outside the area to get a decent income. There is no hope in the area 
itself, how employment is available, while there are no factories and industries that exist in Aceh. Even though the community very often and familiarly heard that Aceh had a lot of profit sharing funds, unfortunately the people did not know anything, wherever the money was distributed by the government.

\subsection{Solutive Efforts of the Aceh Government in Poverty Alleviation}

The stagnant factor of government is caused by two factors, internal and external. For internal factors, it comes from the community itself, that each aid is a gift, not as a medium for making changes with the motivation of government assistance. Government assistance has not been a trigger for the community to reduce poverty. A lack of work ethic, thinking that is still consumptive and seeing things that are not far ahead, making government assistance only to be enjoyed for a moment.

External factors, the local government is considered not pro-people. Many government programs are forced only to the needs of financial accountability, but assistance is not on target and not based on community needs. In addition, the existence of polemic between the legislature and executive also impacts on the smooth implementation of the program. The ongoing assistance and programs that are less innovative (monotonous) are also external causes of poverty in Bengkulu and Aceh.

For this reason, the government must ensure that any assistance for poverty alleviation must be given the right target, according to the needs, climate and habits of the local community. Therefore, the government must plan and run innovative programs, not monotonous in one programs, because it does not necessarily provide assistance, especially with the ability and knowledge to be possessed, such as the assistance of oxen, not all communities are able to develop the assistance.

The lack of assistance is also a problem, people with low stigma of thinking, not to mention the lack of work ethic, but there must be ongoing assistance, by providing integrative understandings of the benefits of assistance and awareness-raising to make the economy better.

The low work ethic of the Acehnese could be due to the community mindset. That every aid is a gift, not as a medium for making changes with motivation from government assistance. Government assistance has not been a trigger for people to make changes to their lives. The community is still struggling with effective thinking patterns that are not productive, meaning that the trend is now developing in the community is receiving assistance for consumption, not as a medium to increase productivity. The result is that all products are shipped from outside the region and are only a user of the product.

The effort that can be taken is to provide character education for the community. Character education is understood as an effort to cultivate intelligence in thinking, appreciation in the form of attitudes, and practice in the form of behavior that is in accordance with the values of the community in interacting with each other, God, and their environment. Character values that apply in society include honesty, independence, courtesy, social glory, and logical thinking intelligence. Therefore, one of the objectives of planting character education is to transfer knowledge or train certain skills.

As for the ongoing solutions from the government to tackle poverty, a village fund program was held. The Village Fund is part of the central government's program to accelerate rural development and also alleviate poverty. 
The main problem in efforts to alleviate poverty in Indonesia is currently related to the fact that economic growth is not spread evenly across the entire territory of Indonesia, this is evidenced by the high income disparity between regions.

In addition, poverty is also a causal relationship, which means that high levels of poverty occur because of low per capita income, low per capita income occurs because per capita investment is also low. The low level of per capita investment is caused by per capita domestic demand. And so on, so as to form a circle of poverty as a cause and effect relationship. ${ }^{13}$

The poverty reduction program in Indonesia, through a program in the form of direct community assistance with an empowerment approach, is one form of alternative development that requires the community to be able to be independent in fulfilling their daily needs. Within this framework the current community-based empowerment program that is currently run by the government is through a village fund program.

The program is based on Law No. 6 of 2014 concerning Village Funds. The program also marks the government's seriousness to change the logic of the project approach into a program. This is done by consolidating community empowerment programs that exist in various ministries/institutions. Village funds are assistance provided by the Government in the context of accelerating village development and poverty alleviation, community empowerment and strengthening government and villages. ${ }^{14}$

Village funds have been shown to have an influence on poverty reduction and reduction of unemployment in the village even though it is not yet significant. ${ }^{15}$ Village funds are government assistance in the context of accelerating development, poverty alleviation, community empowerment and strengthening village governance.

The Governor of Aceh Province, who is also the Chair of the Coordinating Team for the Acceleration of Poverty Reduction in Aceh, said that Aceh was actually quite helped by the presence of village funds programs allocated from the National Budget. From 2015 to 2018, the total budget for Aceh has reached Rp. 14.8 trillion. With that support, it is expected that each village can develop and grow into an independent village.

To encourage this achievement, the Governor of Aceh Province invited all parties to consult to formulate the best steps in empowering gampong by optimizing the existing budget. The aim is to improve the development of people's welfare, so that it can automatically reduce poverty in Aceh. In addition, for poverty alleviation, district and city governments in Aceh are invited to look for other funding schemes, without being fixed on regular funds (APBK / APBD) whose value is relatively small.

The Aceh Government targets the poverty rate in Aceh to decrease by at least 1 percent per year. That number has actually been achieved during the government period of 2007-2012. Where in that year poverty dropped to reach 8 percent or 1.6 percent per year. It's just that in the next period it starts moving slowly, which is around 0.5 percent. Looking at the highest budget in Aceh in Sumatra, Aceh should not be worthy of being a poor area For this reason, the government needs to think seriously about reducing poverty in Aceh.

\footnotetext{
${ }^{13}$ Aulia Sofyan, Pengamat perencanaan pembangunan daerah, in Media Sapa Indonesia.

${ }^{14}$ Ibid.

${ }^{15}$ Hasil penelitian Bappeda Aceh, 2014.
} 


\section{Conclusion}

Poverty alleviation is a program that is a major concern for policy makers. The program is outlined in the Medium Term Development Plan (RPJM) and supplemented through the relevant agencies as stated in the vision and mission of the elected governor. The poverty alleviation program was annulled in the effort of venture capital assistance, seed assistance, livestock, boats, education and health assistance.

Factors of poverty that occur in Aceh are caused by two things, namely structural and cultural. Structurally the factor is still the slow pace of poverty alleviation because policies and implementation of poverty alleviation programs are not on target. Assistance provided is not based on the initial assumption of the level of needs and suitability of the community with the type of assistance. Indeed aid is channeled by analyzing the needs and psychology of the community. Providing livestock assistance must be based on land owned by residents. The government also seems to force a program to be given to the community so that the program is completed, without considering the time of implementation which sometimes only remains for a matter of months, so that assistance is not effective in relation to the time of implementation.

Distribution of aid which is sometimes still loaded with connectivity, nepotism, and profit sharing deals, even in the aspect of reducing the amount of aid, with a record of accountability in accordance with the amount of funds in the program, is a difficult problem to be able to provide assistance to the community quickly, precisely and efficiently . The long polemic of budget approval between the executive and the legislature is also a dark record of the slow implementation of the program for the community. The delay in budget approval for months, is very detrimental at the stage of program implementation which only lasts a few months, moreover for Aceh the funds that will be rolled out for community improvement are only based on APBA.

The cause of poverty is culturally, this is related to the character of the community which contributes greatly to poverty. Like the low work ethic of the community. This work ethic belongs to what is often called cultural poverty. Unlike structural poverty, cultural poverty actually comes from within individuals and groups in society. Laziness, helplessness, lack of work ethic, and maintained habits cause them to be poor. The low work ethic can also be caused by the community mindset. That every aid is understood as a gift, not as a medium for making changes with motivation from government assistance. Government assistance has not been a trigger for people to make changes to their lives. Not to mention the community mindset that is consumptive and unproductive, of course this must also be a concern of the government. For this reason, the government must plan and implement innovative programs, not monotonous in one program, because not necessarily all communities are able to manage the assistance provided, especially with the influence of the abilities and knowledge possessed, such as the assistance of oxen, not all communities are able to develop assistance that is.

The absence of ongoing assistance is also a problem, people with low stigma of thinking, not to mention the lack of work ethic, are certainly not enough just to be given assistance, but there must be ongoing assistance, by providing integrative understandings of the benefits of assistance and awareness-raising to make the economy better. 


\section{References}

Asghar Ali Engineer, Islam dan Teologi Pembebasan, Terj. Agung Prihantoro, Cet. II, (Yogyakarta: Pustaka Pelajar, 2000).

Asghar Ali Engineer, Islam dan Teologi Pembebasan, (Pustaka Pelajar: Yogyakarta, 2000).

Badan Pusat Statistik (BPS) Provinsi Bengkulu, Profil Kemiskinan Provinsi Bengkulu Maret 2018, No. 45/07/17/Th. XII, 16 Juli 2018.

Badan Pusat Statistik (BPS) Provinsi Bengkulu, Profil Kemiskinan Provinsi Bengkulu Maret 2018, No. 45/07/17/Th. XII, 16 Juli 2018.

Badan Pusat Statistik (BPS) Provinssi Aceh, Profil Kemiskinan dan Ketimpangan Pengeluaran Penduduk Aceh Maret 2018, No. 31/07/Th.XXI, 16 Juli 2018.

Daryono, "Evaluasi Kebijakan Pengentasan Kemiskinan di Kecamatan Samarinda Utara Kota Samarinda (Menilik Program Nasional Pemberdayaan Masyarakat Mandiri)", dalam Jurnal Administrative Reform, Vol. III, No. 2, (2015).

Elbina Mamla Saidah, “Konsep Kepemimpinan dalam Islam”, dalam Jurnal al-Ishlah, Vol. VI, (2014).

Elly M. Setiadi dan Usman Kolip, Pengantar Sosiologi: Pemahaman Fakta dan Gejala Permasalahaan Sosial: Teori, Applikasi Dan Pemecahannya, (Jakarta: Kencana, 2011).

Firmansyah, "Akrabnya" Hasrat Korupsi dan Angka Kemiskinan di Bengkulu, dalam Kompas.com. Lihat dalam http://regional.kompas.com/read/2017/07/17/07000091/akrabnya-hasrat-korupsi-dan-angka-kemiskinan-di-bengkulu diakses pada 25 September 2017.

Heru Cahyono, "Evaluasi Atas Pelaksanaan Otonomi Khusus Aceh: Gagal Menyejahterakan Rakyat Dan Sarat Konflik Internal", dalam Jurnal Penelitian Politik, Vol. IX, No. 2, (2012).

M. Adams and H. Howell, Restributive Land Reform in Southern Africa, (ODI: Natural Resources Perspective, No. 64, 2001).

M. Subhan Setowara, Berteologi Melawan Kemiskinan, dalam KOMPAS, 6 November 2004.

Martin Chen, Teologi Gustavo Gutierrez, (Yogyakarta: Kanisius, 2002).

Muhammad Istan, "Pengentasan Kemiskinan Melalui Pemberdayaan Ekonomi Ummat Menurut Perspektif Islam”, dalam Jurnal al-Falah, Vol. II, No. 1, (2017).

Narvan Akbar, Ini Lima Program Prioritas Pemprov Bengkulu Mengentaskan Kemiskinan, lihat dalam https://jpp.go.id/peristiwa/lintas-daerah/302947-ini-lima-programprioritas-pemprov-bengkulu-dalam-mengentaskan-kemiskinan diakses pada 26 September 2018.

Randi, Staretegi Pemerintah entaskan kemiskinan di Aceh, Rubrik "Berita" dalam Kanal Aceh: Berita Terpercaya. Lihat dalam https://www.kanalaceh.com/2018/06/04/staretegi-pemerintahentaskan-kemiskinan-di-aceh/ diakses pada 27 September 2018.

St. Nasriah AR., "Dakwah dan Problematika Kemiskinan Struktural", dalam Tabligh, Edisi $X X I V$, (Desember 2011).

Tasmin, Teologi Kaum Tertindas, (Kediri: STAIN Kediri Press, 2009).

Website Resmi Pemerintah Provinsi Bengkulu. https://bengkuluprov.go.id/program-prioritas/ diakses pada 26 September 2018.

Yetti Rahmadani, Provinsi Bengkulu Masih Menyandang Predikat Termiskin Ke Dua Setelah Aceh, dalam RMOL Bengkulu http://www.rmolbengkulu.com/ Diakses pada 13 Juli 2018, Pukul 20:53. 